\title{
INFLUENCE OF COMPETENCE, INDEPENDENCE, SPIRITUAL QUOTIENT, EMOTIONAL QUOTIENT, AND AUDIT TENURE ON AUDIT QUALITY
}

\author{
Ready Wicaksono*1), Mispiyanti ${ }^{2}$ \\ Sekolah Tinggi Ilmu Ekonomi Balikpapan ${ }^{1)}$, Universitas Putra Bangsa ${ }^{2)}$ \\ ready@stiebalikpapan.ac.id ${ }^{1)}$,mispiyanti@gmail.com ${ }^{2)}$
}

\begin{abstract}
Audit quality is the probability of an assessment given by the auditor about the discovery of a violation in the client's accounting system and reports the violation. The purpose of this study is to obtain empirical evidence of competence, independence, spiritual quotient, emotional quotient, and audit tenure variables on audit quality. This research is quantitative. The population in this study is the Public Accountant Office in Yogyakarta with the sample selection method that is convenience sampling. The data is taken from respondents' responses to positive and negative statements contained in the questionnaire. Data processing and hypothesis testing techniques using SPSS version 22. The results of this study prove that competence, independence, spiritual quotient, emotional quotient, and audit tenure have a significant positive effect on audit quality. This shows that an auditor must have good personal quality, adequate knowledge, and special expertise in his field, not influenced by other parties, and is obliged to be honest not only to the management and owners of the company but also users of financial statements, have a spiritual and emotional good, and a deeper and more complete understanding of the company's operational activities, along with the increase in the number of years of the audit engagement with the company so that it has an impact on the quality of audits produced.
\end{abstract}

Keywords: quality audit, competence, independence, spiritual quotient, emotional quotient, audit tenure.

*Corresponding author:

Email: ready@stiebalikpapan.ac.id

DOI: https://doi.org/10.33369/j.akuntansi.11.2.137-148

\section{INTRODUCTION}

There is a systematic, independent and documented process in the audit to obtain evidence to be evaluated objectively so that it is known to what extent the audit criteria are met (Dewi \& Dwirandra, 2018). The fact of the audit is the process of proof conducted by an independent person (Impartial) against a management's assessment using judgment and evidence that proves (Evidential Matter). Every business entity or company should be willing to conduct audits to provide feedback on the performance that has been done. In addition to being used for the company, the results of the audit can also be used by outside parties such as OJK (Alim, Hapsari, \& Purwanti, 2007). Concerning this, the function of the Public Accountant here is as an intermediary that connects the management of the firm with outside parties of the firm. From the profession of a public accountant, the public wants a free and impartial objective assessment of the information provided by the firm's management in the financial statements.

The functions and roles of auditors are needed for the business world, therefore auditors have a responsibility to produce quality audits. From the outset, audit quality has been defined as results that depend on the existence of a particular auditor's assessment (Knechel, Krishnan, Pevzner, Shefchik, \& Velury, 2013). The widely used definition Deangelo, (1981) defines the quality of probability audit assessments that auditors give about the discovery of infringements in the client's accounting system, and reports such infringements (Knechel et al., 2013). The real audit is done by a human being. Computers or even robots can help the auditing process, but it is still human beings who determine in giving consideration and decision making. Therefore, an Auditor who examines the Financial Statements of an entity must uphold the ethics of the accountant profession that has been regulated by the Indonesian Institute of Accountants (IAI). 
In 2019, it was an integrity test for Public Accountants in the country. During a heated political year, there was a rumor of alleged manipulation of data in the financial statements of the Red Plate company of public pride of the country, namely PT. Garuda Indonesia (Persero) Tbk. It is signaled because of the failure to identify the type of account in the presentation of financial statements from the red plate company. in this case is the airline company PT Garuda Indonesia Persero Tbk in 2018 which was audited by Kasner Sirumapea and Public Accounting Firm (KAP) Tanubrata, Sutanto, Fahmi, Bambang \&Rekan. The Ministry of Finance (Ministry of Finance) and the Financial Services Authority (OJK) have agreed to identify violations in the 2018 annual financial statements of PT Garuda Indonesia (Persero) Tbk (GIAA). Therefore, both supervisory authorities agreed to impose sanctions on auditors, auditing firms, and companies. This began when two Garuda commissioners considered Garuda Indonesia's 2018 financial statements were incompatible with the Statement of Financial Accounting Standards (PSAK). Both renounced to sign the annual accounts. Accordingly, Garuda Indonesia is expected to post a loss of USD 244.95 million in 2018. However, in the 2018 financial statements, the company posted a net income of $\$ 809.84 \mathrm{~K}$, which increased significantly over 2017, which lost \$216.58M.

Attribute theory is a theory of Harold Kelley (1972-1973) in Rahmi \& Sovia, (2017), concerning how a person concludes "what is the cause" so that it becomes the basis for doing an action or deciding to act in certain ways. Personal characteristics are internal factors that encourage someone to carry out an activity that determines audit quality. Attribution theory is a grand theory in this study because it will examine the factors that influence auditors on audit quality, especially on the characteristics of the auditors themselves.

Some research proves that audit quality is influenced by several variables such as competence, independence, spiritual quotient, emotional quotient, and audit tenure. Darayasa \& Wisadha, (2016) said that competencies mastered by a person who has procedural knowledge and expertise are shown from a lot of audit experience. A good understanding of the financial statements can be done by a well-experienced auditor. Auditors are also able to provide reasonable explanations for errors in financial statements and can classify errors based on audit objectives and the structure of accounting systems (Darayasa \& Wisadha, 2016). The results of the research Octavia \& Widodo, (2015), Ramlah et al., (2018), Iryanie, (2017), and Halim et al., (2014) proved the competence to positively affect the quality of the audit. This is in contrast to the research conducted by Rakatama et al., (2016) proving the competence of auditors has no positive effect on the quality of audits. Refers to the results of research that has been done, the hypothesis is competence positively affects audit quality.

Independence influences the quality of audits. Independence is the willingness and ability of auditors to maintain a free or unbound attitude by any interests and pressures from anyone, including their interests, in determining the right decisions at the planning, implementation, and reporting stages of audit results. For auditors who maintain an attitude of independence, the quality of audits produced will be better (Harsanti \& Whetyningtyas, 2014). The results of the research by Halim et al., (2014), Octavia \& Widodo, (2015), Iryanie, (2017), and Ramlah et al., (2018) proved independence positively impacted the quality of the audit. This is different from the research conducted by Karnisa \& Chariri, 2015) proving independence has no positive effect on the quality of audits. Refers to the results of research that has been done, the hypothesis is independence positively affects audit quality.

In addition to competence and independence, the spiritual quotient affects the quality of audits. Spiritual intelligence is someone who can interpret the values of life, morals, and actions so that he becomes a positive person, full of peace and wise towards others to be able to live his life positively (Laksmi \& Sujana, 2017). Spiritual intelligence is one of the things that can influence ethical behavior in the organization Drakulevski \& Veshoska, (2014) and moral 
pressure (Hannani, Kamali, Amiri, \& Hosseini, 2018). The results of the research by Fauzan \& Setyorini, (2017), Kusuma \& Sukirman, (2017), and Pasaribu et al., (2018) prove spiritual quotient affects the quality of audits. Refers to the results of research that has been done, the hypothesis is spiritual quotient positively affects audit quality.

The emotional quotient is considered to affect the quality of audits. Emotional intelligence is the ability to control emotions as well as self-mastery to make decisions in calm conditions. Goleman, (2015) defines emotional intelligence as someone who understands personal feelings as well as other people, encourages himself, and can manage emotions well in socializing. Interpersonal success stemming from emotional intelligence will be one of the most important skills of the 21st century. Emotions add depth and richness to life. Without feeling one's actions will be more like a computer, thinking but without passion (Widhianningrum, 2017). The results of the research by Fauzan \& Setyorini, (2017), Kusuma \& Sukirman, (2017), and Pasaribu et al., (2018) prove emotional quotient affects the quality of audits. Refers to the results of research that has been done, the hypothesis is emotional quotient positively affects audit quality.

Audit tenure or the period of audit agreement may affect the quality of the audit. The audit agreement period has become a public debate. If the alliance period is done for a long time will create excessive closeness between the client and the auditor so that the independence and objectivity of the auditor will later decrease (Pramaswaradana \& Astika, 2017). The statement is similar to the research Al-Thuneibat et al., (2011) which states that a long alliance period can affect the objectivity of auditors in work. If done in a short time will make the auditor less maximal in obtaining information and understanding the client's corporate environment. Hamid, (2013) states that a short alliance period makes auditors short of time to understand the client's business environment so that they are less able to better assess information. The results of research by Salehi et al., (2019), Junaidi et al., (2012), and Siregar et al., (2012) tenure audit affect audit quality. Refers to the results of research that has been done, the hypothesis is audit tenure positively affects audit quality.

The novelty of this research is the use of competence, independence, spiritual quotient, emotional quotient, and audit tenure. The use of these variables is based on the suitability of these variables against the background of the problems raised in this study and is an amalgamation of variables in previous studies. Thus, the purpose of this study is to obtain empirical evidence of factors that affect the quality of audits.

So, based on the description, the hypotheses built in this study are:

$\mathrm{H}_{1}$ : Competence positively affects audit quality.

$\mathrm{H}_{2}$ : Independence positively affects audit quality.

$\mathrm{H}_{3}$ : Spiritual quotient positively affects audit quality.

$\mathrm{H}_{4}$ : Emotional quotient positively affects audit quality.

$\mathrm{H}_{5}$ : Audit tenure positively affects audit quality.

\section{RESEARCH METHODS}

The population in the research is the Public Accounting Firm in Yogyakarta. The reason is that Yogyakarta is a city that already has many KAP large and small, which demands the existence of independent auditors in conducting an examination of financial statements which is a form of involvement in determining the quality of audits. The method of sampling used is convenience sampling, which is a sampling technique by disseminating several questionnaires using questionnaires that return and can be processed. The sample in this study is an independent auditor working at KAP Yogyakarta.

This research is quantitative research using primary data through surveys by disseminating questionnaires to respondents who are the subjects of the study, namely the Public Accounting Firm (KAP) with a total of 100 auditors. The questionnaire was distributed 
directly online to public accountants in Yogyakarta on November 20-30, 2019. In this study, the data was taken from respondents' answers to positive statements and negative statements contained in the questionnaire, and each respondent was asked for their opinion on the statements. The Likert scale is utilized in this study to quantify each variable.

The variable of the audit quality is the probability that the auditor will not report the audit report with a reasonable opinion without exception to financial statements containing material errors. The question asked was adopted from a research questionnaire conducted by Oklivia \& Marlinah, (2014) consisting of 10 question items. The competence of auditors is auditors who with sufficient and explicit knowledge and experience can conduct audits objectively, carefully, and carefully. The question asked was adopted from a research questionnaire conducted by Oklivia \& Marlinah, (2014) consisting of 10 questions. The Independence is the Accountant's Code of Conduct states that independence is the expected attitude of a public accountant not to have a personal interest in the performance of his duties. independence is a free attitude that is expected of an auditor not to be easily influenced, does not favor any party in the implementation of its duties, so as not to harm any party,. Independence was measured using 8 question items from the study (Oklivia \& Marlinah, 2014). The spiritual quotient is based on Zohar \& Marshall, (2007) state that spiritual intelligence is someone who can solve the problem of meaning, which can place himself in a wider context and can live a more meaningful life. This variable measurement uses questionnaire instruments, with a four-point Likert scale model with 8 items developed by (Jamaluddin \& Indriasari, 2011).

Emotional intelligence is someone who can understand their emotions so that they can manage these emotions well, can encourage themselves, can understand the emotions and personalities of others in socializing (Goleman, 2015). This variable measurement uses questionnaire instruments, with a 4-point Likert scale model with 5 dimensions adopted from (Jamaluddin \& Indriasari, 2011). Audit tenure is the period of alliance between KAP and the same auditee (Hamid, 2013). Measurement of audit tenure uses the length of the KAP relationship with the client.

The illustration of the conceptual frame in this research is shown in Figure 1 below:

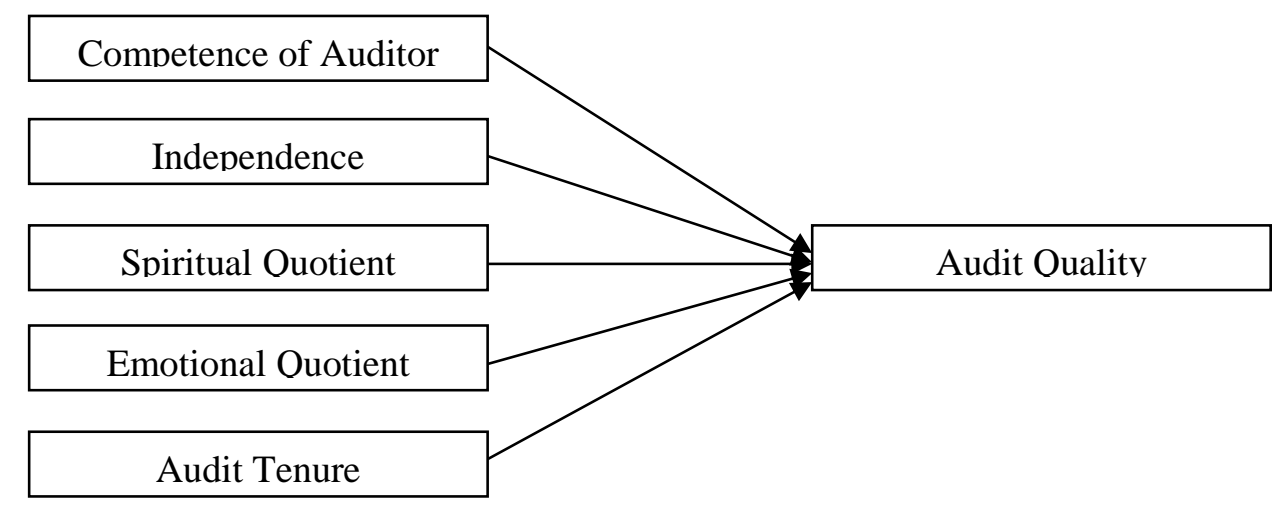

Figure 1. Conceptual Framework

Source: Researcher, 2019

In addition, the collected data is analyzed with statistical tools in the form of SPSS 25 for Windows as data processing software for validity, reliability test, classic acceptance test, and hypothesis test, from which analyzes and conclusions can then be drawn from the results of the study. The regression model in this study is

$\mathrm{Y}=a+b_{1} X_{1}+b_{2} X_{2}+b_{3} X_{3}+b_{4} X_{4}+b_{5} X_{5}+e$

Description:

Y: Audit Quality

$\mathrm{X}_{3}$ : Spiritual quotient 

$\mathrm{X}_{1}$ : Competence
$\mathrm{X}_{4}$ : Emotional quotient
$\mathrm{X}_{2}$ : Independence
$\mathrm{X}_{5}$ : Audit tenure

\section{RESULTS AND DISCUSSION}

The characteristics of the respondents who completed the questionnaire in this study are shown in Table 1.

Table 1. Characteristics of Respondent

\begin{tabular}{|c|c|c|c|}
\hline Variables & Item & Frequency & Percentage \\
\hline \multirow[t]{2}{*}{ Gender } & Woman & 34 & 34 \\
\hline & Man & 66 & 66 \\
\hline \multirow[t]{3}{*}{ Education } & Bachelor Degree & 68 & 68 \\
\hline & Graduate & 28 & 28 \\
\hline & Postgraduate & 4 & 4 \\
\hline \multirow[t]{4}{*}{ Long relationship with KAP } & 1 year & 15 & 15 \\
\hline & 2 years & 46 & 46 \\
\hline & 3 years & 34 & 34 \\
\hline & 4 years & 5 & 5 \\
\hline \multirow[t]{4}{*}{ Position } & Partner & 8 & 8 \\
\hline & Junior Auditor & 44 & 44 \\
\hline & Senior Auditor & 34 & 34 \\
\hline & Other & 4 & 4 \\
\hline
\end{tabular}

Source: Primary Data, 2019

\section{Validity and Reliability Test}

The beginning stage of the test is the validity test for the variable of audit quality, the variable of competence, independence, spiritual quotient, emotional quotient, and the variable of audit tenure. Based on the results of the validity test shows all questionnaire items have a sig value (2-tailed) $<0.05$ which means that all question items in this study are valid. While based on reliability test shows that all variables have Cronbach Alpha $>0.60$, then the concept of each variable is reliable.

Descriptive analysis of SPSS data results in table 2.

Table 2. Descriptive Analysis

\begin{tabular}{lcccc}
\hline & Minimum & Maximum & Mean & Std. Deviation \\
\hline Competence & 2.00 & 4.00 & 2.5780 & .52601 \\
\hline Independence & 2.00 & 4.00 & 2.5075 & .61720 \\
\hline Spiritual Quotient & 2.00 & 4.00 & 2.6613 & .54277 \\
\hline Emotional Quotient & 2.00 & 4.00 & 2.7020 & .56461 \\
\hline Audit Tenure & 2.00 & 4.00 & 2.5380 & .52758 \\
\hline Valid N (listwise) & & & & \\
\hline Source: Primary Data, 2019 & & &
\end{tabular}

\section{Classic Assumption Test}

The normality test shows that Asymp. Sig. (2-tailed) >0.05, shown in Table 3, which recognizes the normal distribution of the regression model.

Table 3. One-Sample Kolmogorov-Smirnov Test

\begin{tabular}{lll}
\hline & & Unstandardized Residual \\
\hline $\mathrm{N}$ & & 100 \\
\hline Normal Parameters $^{\mathrm{a}, \mathrm{b}}$ & Mean & .0000000 \\
\cline { 2 - 3 } & Std. Deviation & .23441458
\end{tabular}


INFLUENCE OF COMPETENCE, INDEPENDENCE, SPIRITUAL QUOTIENT, EMOTIONAL QUOTIENT AND AUDIT TENURE ON AUDIT QUALITY

Ready Wicaksono, and Mispiyanti

\begin{tabular}{lll}
\hline Most Extreme Differences & Absolute & .093 \\
\cline { 2 - 3 } & Positive & .093 \\
\cline { 2 - 3 } & Negative & -.045 \\
\hline Kolmogorov-Smirnov Z & \\
\hline Asymp. Sig. (2-tailed) & .927 \\
\hline a. Test distribution is Normal. & .356 \\
\hline b. Calculated from data. & \\
\hline Source: Output SPSS, 2019 &
\end{tabular}

Based on the results of the Kolmogorov-Smirnov test in table 3, asymp value is produced. Sig. (2-tailed) at 0.356 . The result can be concluded that residual data in this regression model is distributed normally due to asymp value. Sig. (2-tailed) above 0.05 and the regression model is eligible for further analysis. From the results of the data using SPSS, it was found that, in the collinearity statistics section, the VIF value for all independent variables is less than 10 and the tolerance value is greater than 0.1 , indicating no symptoms of multicolerance.

Table 4. Multicollinearity Test

\begin{tabular}{|c|c|c|c|c|}
\hline \multirow{2}{*}{\multicolumn{2}{|c|}{ Model }} & \multicolumn{2}{|c|}{ Collinearity Statistics } & \multirow[t]{2}{*}{ Conclusion } \\
\hline & & Tolerance & VIF & \\
\hline \multirow[t]{6}{*}{1} & (Constant) & & & \\
\hline & Competence & .351 & 2.846 & Not occur \\
\hline & Independence & .663 & 1.509 & Not occur \\
\hline & Spiritual Quotient & .343 & 2.916 & Not occur \\
\hline & Emotional Quotient & .447 & 2.235 & Not occur \\
\hline & Audit Tenure & .556 & 1.798 & Not occur \\
\hline
\end{tabular}

Source: Output SPSS, 2019

In the heteroscedasticity test, no heteroscedasticity symptoms were found because there was no clear pattern in the scatterplot image as shown in Figure 2, and the distribution of the points in the scatterplot image and also was below the $\mathrm{Y}$-axis (audit quality). This is as (Ghozali, 2018) notes that when there is no clear pattern (wavy, expanded, then narrowed) in the scatterplot image, there is no heteroscedasticity and the dots are dying above and below the number 0 on the $\mathrm{Y}$-axis as shown distribute below:

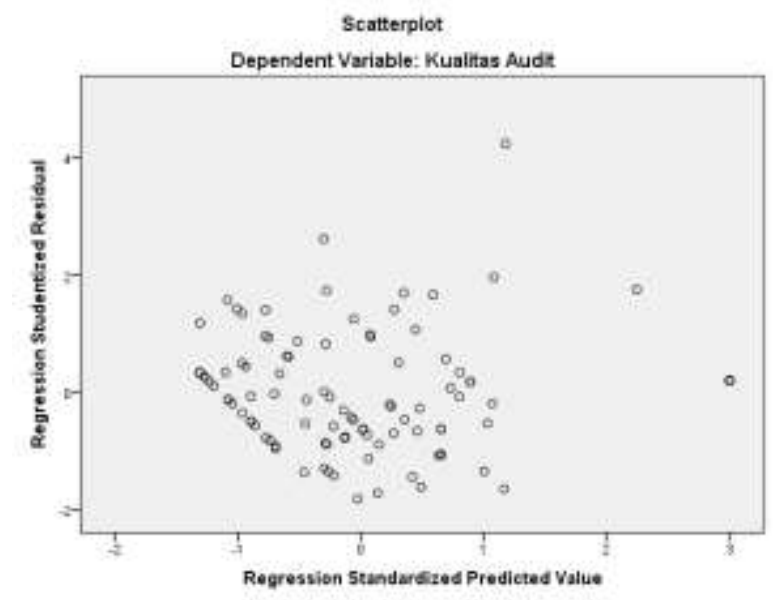

Figure 2. Scatterplot pattern

\section{Hypothesis Test}

The results of the $t$ statistical test can be seen in table 5. Below 
Table 5. t-Test Results (Partial Correlation Analysis)

\begin{tabular}{|c|c|c|c|c|c|c|}
\hline & \multirow[t]{2}{*}{ Model } & \multicolumn{2}{|c|}{$\begin{array}{c}\text { Unstandardized } \\
\text { Coefficients }\end{array}$} & \multirow{2}{*}{$\begin{array}{c}\text { Standardized } \\
\text { Coefficients } \\
\text { Beta }\end{array}$} & \multirow[t]{2}{*}{$\mathrm{t}$} & \multirow[t]{2}{*}{ Sig. } \\
\hline & & $\mathrm{B}$ & $\begin{array}{l}\text { Std. } \\
\text { Error }\end{array}$ & & & \\
\hline \multirow[t]{6}{*}{1} & (Constant) & -.115 & .140 & & -.826 & .411 \\
\hline & Competence & .273 & .078 & .272 & 3.518 & .001 \\
\hline & Independence & .145 & .048 & .170 & 3.011 & .003 \\
\hline & Spiritual Quotient & .283 & .076 & .291 & 3.723 & .000 \\
\hline & Emotional Quotient & .179 & .064 & .191 & 2.790 & .006 \\
\hline & Audit Tenure & .138 & .048 & .176 & 2.863 & .005 \\
\hline
\end{tabular}

Source: Output SPSS, 2019

Based on table 5, the regression model is as follows:

Audit Quality $=-0,115+0,273 \mathrm{X}_{1}+0,145 \mathrm{X}_{2}+0,283 \mathrm{X}_{3}+0,179 \mathrm{X}_{4}+0,138 \mathrm{X}_{5}+\mathrm{e} \ldots \ldots \ldots .(2)$

Based on table 5, the amount of the regression coefficient of competency variables is 0.273 and the value of significance is 0.001 , meaning that competency variables positively affect the quality of audits. For independent variables, the magnitude of the independence regression coefficient is 0.145 and the significance value is 0.003 , meaning that independent variables have a positive effect on audit quality. The magnitude of the coefficient of the spiritual quotient variable is 0.283 and the significance value is 0.000 , meaning the spiritual quotient positively affects the quality of the audit. The amount of emotional quotient regression coefficient is 0.179 and the significance value is 0.006 , meaning that the emotional quotient positively affects audit quality. The amount of the regression coefficient of audit tenure is 0.247 and the significance value is 0.005 , meaning that the audit tenure positively affects the quality of the audit.

Based on table 6, it is known that the adjusted $R$ square value of 0.792 means that the model's ability in this case to be an independent variable in describing dependent variables is $79.2 \%$. While the remaining $20.8 \%$ is influenced by other variables that are not included in the regression model.

Tabel 6. Model Summary

\begin{tabular}{|c|c|c|c|}
\hline Model & R Square & Adjusted R Square & Std. Error of the Estimate \\
\hline \multicolumn{4}{|c|}{$896^{\mathrm{a}}$} \\
\hline $\begin{array}{l}\text { a. Pred } \\
\text { Quot } \\
\text { b. Depe }\end{array}$ & $\begin{array}{l}\text { (Constant), Audit T } \\
\text { ompetence } \\
\text { Variable: Audit Qu }\end{array}$ & e, Spiritual Quotieı & Independence, Emotional \\
\hline
\end{tabular}

Source: Output SPSS, 2019

\section{Discussion}

Auditor Competency Positively Affects Audit Quality

An auditor must have good personal quality, adequate knowledge, and special skills in their field when auditing. The competence of auditors is auditors who with sufficient and explicit knowledge and experience can conduct audits objectively and carefully. Highly educated auditors will have a lot of knowledge about the field they are involved in so that they can know the various problems in more depth. In addition, with extensive science, auditors will be easier to keep up with increasingly complex developments. Based on the description above, competence has two important factors, namely knowledge and experience. A high level of 
knowledge and experience from an auditor will result in a high-quality audit. Attribution theory states that a person will form an idea that will lead to one's behavior in social perception such as knowledge. The results of this study support the research Halim et al., (2014), Octavia \& Widodo, (2015), Iryanie, (2017), and Ramlah et al., (2018) prove the competence to positively affect the quality of audits.

\section{Independence Positively Affects Audit Quality}

An audit can only be effective if the auditor is independent and trusted to be more likely to report a breach of an agreement between the principal (shareholders and creditors) and the agent (manager). An independent auditor is an auditor who is not easily influenced, is on either side, and is required to be honest not only with management and the owners of the company but also with other parties who use financial statements that trust the results of his work. When an auditor is independent, he or she gives a true assessment of the audited financial statements without placing any burden on any party. Then his assessment reflects the actual state of an audited company. Thus, all interested parties can rely on the guarantee of the reliability of the auditor's report. Internal and external attribution has been stated to affect individual performance evaluations (auditor) (Luthans, 2012) (Pujaningrum, 2012). The conclusion is that the higher the independence of an auditor, the better the quality of the audit. These results according to research by Halim et al., (2014), Octavia \& Widodo, (2015), Iryanie, (2017), and Ramlah et al., (2018) prove independence has a positive effect on audit quality.

\section{Spiritual Quotient Positively Affects Audit Quality}

Attribution theory explains the internal causes that refer to aspects of individual behavior that exist within a person. Its relationship with the spiritual quotient is in determining the quality of audits. If there is an internal factor that is spiritual quotient will result in behavior arising from auditors. A person who has a good spiritual quotient will have one's ability to interpret life and one's ability to interpret the values, morals, and deeds of fellow living beings and be able to make himself as a positive person, full of peace and wise towards his fellow man to be able to live his life positively. A person who ignores spiritual values is likely to use all means to pursue his or her achievements, the person is likely to be dishonest to achieve the desired achievement (Laksmi \& Sujana, 2017). These results according to research by Fauzan \& Setyorini, (2017), Kusuma \& Sukirman, 2017), and Pasaribu et al., (2018) prove spiritual quotient affects the quality of audits.

\section{Emotional Quotient Positively Affects Audit Quality}

Attribution Theory explains internal causes that refer to aspects of individual behavior that exist within a person. The relationship with emotional intelligence is in determining the quality of audits. If there are internal factors that are emotional intelligence will result in behavior arising from auditors. One of the hallmarks of emotional intelligence is understanding oneself, recognizing self-emotions, and being able to manage self-emotions (Goleman, 2015). An individual with emotional intelligence can understand his or her role in society leading to an understanding that the individual must follow the norms and values that surround him or her. With the ability to recognize and manage self-emotions, individuals can act ethically following applicable norms and values and maintain relationships with the community (Wardana \& Mimba, 2016). These results according to research by Fauzan \& Setyorini, (2017), Kusuma \& Sukirman, (2017), and Pasaribu et al., (2018) prove emotional quotient affects the quality of audits. 


\section{Audit Tenure Positively Affects Audit Quality}

The longer the alliance period of auditors and clients can increase the auditor's knowledge of the client's company so that the quality of the audit increases. The length of time auditors can improve the quality of audits, as auditors may need time to gain expertise in their business. This indicates a deeper and complete understanding of the company's operational activities for auditors, in line with the increasing number of years of audit agreements with the company. In carrying out its duties, auditors must be able to maintain independence as the alliance year increases. With this independent attitude, auditors carry out the audit process following established standards and do not attach importance to personal interests to produce good quality audit results (Nugrahanti \& Darsono, 2014). This amplified the presence of dispositional attributions on the behavior of individuals that exist in a person referring to the surrounding environment that affects behavior (external factors) such as rules.

\section{CONCLUSIONS AND SUGGESTION}

This study was conducted to determine the factors that affect the quality of audit empirically. The results of this study prove that competence, independence, spiritual quotient, emotional quotient, and audit tenure have a significant positive effect on audit quality. This research is limited only to public accountants in Yogyakarta and the data collected and analyzed using questionnaire methods, thus allowing the filling of questionnaires of respondents who are not serious and can cause misleading results. Advice for future research is that future research can use respondents from different research places. Then can use the interview method so that it gets better results compared to using the questionnaire method. 
INFLUENCE OF COMPETENCE, INDEPENDENCE, SPIRITUAL QUOTIENT, EMOTIONAL QUOTIENT

AND AUDIT TENURE ON AUDIT QUALITY

Ready Wicaksono, and Mispiyanti

\section{REFERENCES}

Al-Thuneibat, A. A., Al Issa, R. T. I., \& Baker, R. A. A. (2011). Do audit tenure and firm size contribute to audit quality?: Empirical evidence from Jordan. Managerial Auditing Journal, 26(4), 317-334. https://doi.org/10.1108/02686901111124648

Alim, M. N., Hapsari, T., \& Purwanti, L. (2007). Pengaruh Kompetensi Dan Independensi Auditor Terhadap Kualitas Audit Dengan Etika Auditor Sebagai Variabel Moderasi. Simposium Nasional Akuntansi X, 1-26. https://doi.org/10.35141/jraj.v1i2.60

Darayasa, I., \& Wisadha, I. (2016). Etika Auditor Sebagai Pemoderasi Pengaruh Kompetensi Dan Independensi Pada Kualitas Audit Di Kota Denpasar. E-Jurnal Akuntansi, 15(1), 142-170.

Deangelo, L. E. (1981). Auditor size and audit fees. Journal of Accounting and Economics, 3(May), 183-199.http://dx.doi.org/10.1016/0165-4101(81)90002-1

Dewi, E. Y., \& Dwirandra, A. A. N. B. (2018). Kompetensi dan Moral Reasoning Memoderasi Pengaruh Independensi pada Kualitas Audit di Kantor Akuntan Publik Provinsi Bali. EJurnal Akuntansi, 23, 240. https://doi.org/10.24843/eja.2018.v23.i01.p10

Drakulevski, L., \& Veshoska, A. T. (2014). "The Influence of Spiritual Intelligence on Ethical Behaviour in Macedonian Organization. Proceedings of the Business Systems Laboratory - 2nd International Symposium, 46-51.

Fauzan, M. F. A., \& Setyorini, D. (2017). The Effect of Emotional Quotient, Spiritual Quotient , and Client Pressure on Audit Quality. Jurnal Profita, 7(2), 1-19.

Ghozali, I. (2018). Aplikasi Analisis Multivariate Dengan Program IBM SPSS 25 (9th ed.). Semarang: Badan Penerbit -UNDIP.

Goleman, D. (2015). Emotional Intelligence : Kecerdasan emosional mengapa EI lebih penting daripada IQ. Jakarta: PT Gramedia Pustaka Utama.

Halim, A., Sutrisno, T., \& Achsin, M. (2014). Effect of Competence and Auditor Independence on Audit Quality with Audit Time Budget and Professional Commitment as a Moderation Variable. International Journal of Business and Management Invention, 3(6), 64-74.

Hamid, A. (2013). Pengaruh Tenur KAP dan Ukuran KAP Terhadap Kualitas Audit. Jurnal Akuntansi, 1(1).

Hannani, S., Kamali, N., Amiri, F., \& Hosseini, A. F. (2018). The relationship between Spiritual Intelligence and Moral Distress in Operating Room Students. Medical Ethics Journal, 11(42), 23-33.

Harsanti, P., \& Whetyningtyas, A. (2014). Pengaruh Kompetensi, Independensi, Dan Profesional Auditor Terhadap Kualitas Audit. Jurnal Sosial Dan Budaya, 7(1), 16-37. https://doi.org/10.34204/jiafe.v2i1.534

Iryanie, L. D. (2017). the Effect of Competence, Independence and Workload on Audit Quality. Journal of Humnities and Social Studies, 1(1), 1-4. https://doi.org/10.30957/jares.v2i2.404

Jamaluddin, \& Indriasari, R. (2011). Pengaruh Kecerdasan Intelektual , Kecerdasan Emosional , dan Kecerdasan Spiritual terhadap Etika Mahasiswa Akuntansi Fakultas Ekonomi Universitas Tadulako. Pamator, 4(1), 46-56.

Junaidi, Miharjo, S., \& Hartadi, B. (2012). Does auditor tenure reduce audit quality? Gadjah Mada International Journal of Business, 14(3), 303-315. https://doi.org/10.22146/gamaijb.5478

Karnisa, D. A., \& Chariri, A. (2015). Pengaruh Kompetensi dan Independensi Terhadap Kualitas Audit dengan Motivasi dan Etika Auditor sebagai Variabel Moderasi (Studi Empiris Pada Kantor Akuntan Publik di Jakarta). Pengaruh Kompetensi Dan Independensi Terhadap Kualitas Audit Dengan Motivasi Dan Etika Auditor Sebagai Variabel Moderasi 
(Studi Empiris Pada Kantor Akuntan Publik Di Jakarta), 4(2), 55-63.

Knechel, W. R., Krishnan, G. V., Pevzner, M., Shefchik, L. B., \& Velury, U. K. (2013). Audit quality: Insights from the academic literature. Auditing, 32(SUPPL.1), 385-421. https://doi.org/10.2308/ajpt-50350

Kusuma, S. P., \& Sukirman. (2017). The Effect of Emotional Intelligence and Auditor's Experience on Audit Quality with Independence as A Moderating Variable. Accounting Analysis Journal, 6(3), 370-379. https://doi.org/10.15294/aaj.v6i3.18218

Laksmi, R. A., \& Sujana, I. K. (2017). Pengaruh Kecerdasan Intelektual, Kecerdasan Emosional, dan Kecerdasan Spiritual Terhadap Pemahaman Akuntansi. E-Jurnal Akuntansi Udayana, 21(2), 1373-1399.

Nugrahanti, Y., \& Darsono. (2014). Pengaruh Audit Tenure, Spesialisasi Kantor Akuntan Publik Dan Ukuran Perusahaan Terhadap Terhadap Kualitas Audit. Diponegoro Journal Of Accounting, 03(03), 1-9.

Octavia, E., \& Widodo, N. R. (2015). The Effect of Competence and Independence Of Auditors on the Audit quality. Research Journal of Finance and Accounting Www.Iiste.Org ISSN, 6(3), 1-6. Retrieved from www.iiste.org

Oklivia, \& Marlinah, A. (2014). Pengaruh Kompetensi, Independensi Dan Ukuran Auditee Terhadap Kualitas Audit. Jurnal Bisnis Dan Akuntansi, 16(2), 143-157. https://doi.org/10.18860/em.v5i2.2861

Pasaribu, S., Zahreni, D. S., \& Hasnida. (2018). The Influence of Spiritual Quotient and Emotional Quotient to Internal Audit Judgment. International Research Journal of Advanced Engineering and Science, 3(2), 218-221.

Pramaswaradana, I. G. N. I., \& Astika, I. B. P. (2017). Pengaruh Audit Tenure, Audit Fee, Rotasi Auditor, Spesialsiasi Auditor, Dan Umur Publikasi Pada Kualitas Audit I. Journal of Chemical Information and Modeling, 53(9), 1689-1699. https://doi.org/10.1017/CBO9781107415324.004

Pujaningrum, I. (2012). Analisis Faktor-Faktor yang Mempengaruhi Tingkat Penerimaan Auditor Atas Penyimpangan Perilaku Dalam Audit. Diponegoro Journal Of Accounting, 1(1), 870-884.

Rahmi, F., \& Sovia, A. (2017). Dampak Sistem Pengendalian Internal, Prilaku Tidak Etis, Dan Moralitas Manajemen Terhadap Kecenderungan Kecurangan Akuntansi Pada Perusahaan Developer Di Pekanbaru. Jurnal Al-Iqtishad, 13(1), 48. https://doi.org/10.24014/jiq.v13i1.4388

Rakatama, P., Tugiman, H., \& Dillak, V. J. (2016). Influence of Competence and Ethics of Auditors on Audit Quality. E-Proceeding of Management, 3(3), 117-118.

Ramlah, S., Syah, A., \& Dara, M. A. (2018). The effect of competence and independence to audit quality with auditor ethics as a Modernation variable. International Journal of Scientific and Technology Research, 7(9), 6-10.

Salehi, M., Fakhri Mahmoudi, M. R., \& Daemi Gah, A. (2019). A meta-analysis approach for determinants of effective factors on audit quality: Evidence from emerging market. Journal of Accounting in Emerging Economies, 9(2), 287-312. https://doi.org/10.1108/JAEE-03-2018-0025.

Siregar, S. V., Amarullah, F., Wibowo, A., \& Anggraita, V. (2012). Audit tenure, auditor rotation, and audit quality: The case of Indonesia. Asian Journal of Business and Accounting, 5(1), 55-74.

Wardana, A. gede A. W., \& Mimba, N. P. S. H. M. (2016). Pengaruh Kecerdasan Intelektual, Kecerdasan Emosional, Kecerdasan Spiritual, dan Gender pada Sikap Etis Mahasiswa Magister Akuntansi Universitas Udayanan. E-Jurnal Ekonomi Dan Bisnis Universitas Udayana, 5(10), 3501-3530.

Widhianningrum, P. (2017). The Influence of Intellectual Intelligence, Emotional Intelligence 
INFLUENCE OF COMPETENCE, INDEPENDENCE, SPIRITUAL QUOTIENT, EMOTIONAL QUOTIENT AND AUDIT TENURE ON AUDIT QUALITY

Ready Wicaksono, and Mispiyanti

and Spiritual Intelligence on Understanding Magnitude of Behavioral Accounting. Journal of Accounting and Business Education, 1(2), 191. https://doi.org/10.26675/jabe.v1i2.8488 Zohar, D., \& Marshall, I. (2007). Kecerdasan Spiritual. Bandung: Mizan. 